\title{
Involvement of Wnt/ $\beta$-catenin pathway in the inhibition of invasion and epithelial-mesenchymal transition in ovarian cancer cells
}

\author{
Belikiz Ekem ${ }^{1}$, Wei Gong1', Lu Han ${ }^{1}$, Xinmei Wang1, Na Liu1, Li Wan¹, Qin Guo ${ }^{2 *}$ \\ ${ }^{1}$ Department of Gynecology, Affiliated Hospital of Traditional Chinese Medicine of Xinjiang Medical University, Urumqi, Xinjiang \\ Uygur Autonomous Region 830000, '2Department of Gynaecology and Obstetrics, The First Affiliated Hospital of Guangdong \\ Pharmaceutical University, Guangzhou, Guangdong Province 510080, China
}

*For correspondence: Email: SDFWE87er@163.com; Tel: +86-20-61321857

Sent for review: 2 April 2020

Revised accepted: 25 June 2020

\begin{abstract}
Purpose: To investigate the effects of zerumbone on cell invasion, epithelial-mesenchymal transition (EMT) and the potential signaling pathway involved in ovarian cancer cells.

Methods: Caov-3 cell proliferation was assessed using 3-(4,5)-dimethylthiahiazo (-z-y1)-3,5-diphenytetrazoliumromide (MTT) assay. Wound healing assay was used to determine Caov-3 cell migration while cell invasion was evaluated using Transwell assay. Protein expression was determined by western blot.

Results: Cell viability was reduced by $5,10,20$, and $50 \mu \mathrm{M}$ zerumbone $(p<0.05)$ in a concentrationdependent manner while cell migration and invasion were inhibited by 10 and $20 \mu \mathrm{M}$ zerumbone $(p<$ 0.05). Protein expression levels of E-cadherin and cytoplasm $\beta$-catenin were upregulated by zerumbone $(p<0.05)$ in a concentration-dependent manner. On the other hand, protein expression levels of $N$ cadherin, vimentin, ZEB1, nuclear $\beta$-catenin, and c-Myc were suppressed by zerumbone $(p<0.05)$ also in a concentration-dependent manner.

Conclusion: The results demonstrate that zerumbone inhibits cell proliferation, migration and invasion, but represses the EMT process via inactivation of Wnt/ $\beta$-catenin signaling pathway.
\end{abstract}

Keywords: Zerumbone, Ovarian cancer, Wnt/ $\beta$-catenin pathway, Epithelial-mesenchymal transition

\begin{abstract}
This is an Open Access article that uses a fund-ing model which does not charge readers or their institutions for access and distributed under the terms of the Creative Commons Attribution License (http://creativecommons.org/licenses/by/4.0) and the Budapest Open Access Initiative (http://www.budapestopenaccessinitiative.org/read), which permit unrestricted use, distribution, and reproduction in any medium, provided the original work is properly credited.
\end{abstract}

Tropical Journal of Pharmaceutical Research is indexed by Science Citation Index (SciSearch), Scopus, International Pharmaceutical Abstract, Chemical Abstracts, Embase, Index Copernicus, EBSCO, African Index Medicus, JournalSeek, Journal Citation Reports/Science Edition, Directory of Open Access Journals (DOAJ), African Journal Online, Bioline International, Open-J-Gate and Pharmacy Abstracts

\section{INTRODUCTION}

Ovarian cancer is the most aggressive cancer and the fifth leading cause of death from gynecological malignancies among women [1]. Approximately $70 \%$ of ovarian cancer cases are diagnosed at the advanced stage due to the lack of specific symptoms during the early stage [2]. Over the past 20 years, chemotherapy for ovarian cancer has consisted mainly of a combination of a platinum agent and a taxane [3]. There is a pressing need for new therapeutic regimens in order to improve the prognosis of ovarian cancer patients.

The epithelial-mesenchymal transition (EMT) is a cell biological process in which epithelial cells are transformed into quasi-mesenchymal cells [4], 
resulting in cells migrating more aggressively to the surrounding tissues [5]. The EMT plays a key role in cancer development and metastasis [6]. Inhibition of EMT is a therapeutic approach in anticancer treatment [7].

The Wnt/ $\beta$-catenin signaling pathway contributes to the regulation of cell proliferation, survival, and stem cell fate [8]. This pathway is strictly controlled in normal cells, and the dysregulation of this pathway is linked to disease progression, including cancer [9]. Increasing evidence reveals that the Wnt/ $\beta$-catenin signaling pathway is involved in cancer development, metastasis, and cancer cell survival [10]. In ovarian cancer, Wnt/ $\beta$-catenin signaling pathway promotes ovarian cancer cell proliferation and is involved in the EMT, leading to cancer initiation and progression [9]. Targeting the $W n t / \beta$-catenin pathway may be effective in the treatment of ovarian cancer.

Zerumbone $\quad(2,6,9,9$-tetramethyl-(2E,6E,10E)cycloundeca-2,6,10-trien-1-one) is a monocyclic sesquiterpene compound (Figure 1A) extracted from the traditional plant Zingiber zerumbet [11]. Zerumbone has many biological effects, including antioxidant, anti-inflammatory, antibacterial, and anti-tumor effects $[12,13]$. In human colorectal cancer, zerumbone has been shown to prevent cancer invasion and metastasis through inhibition of the FAK/PI3K/NF-kB-uPA signaling pathway [14]. By targeting the TGF- $\beta 1$ signaling pathway, zerumbone was shown to repress the tumorigenicity and mobility of triplenegative breast cancer cells [15]. The goal of this investigation was to investigate the effects of zerumbone on cell invasion and the EMT and to elucidate the potential signaling pathway involved in Caov-3 cells, a human ovarian cancer cell line.<smiles>CC1=CCC(C)(C)C=CC(=O)C(C)=CCC1</smiles>

Figure 1: Chemical structure of zerumbone

\section{EXPERIMENTAL}

\section{Cell culture and treatment}

The Caov3 human ovarian cancer cell line was purchased from Wuhan Procell Life Science \&
Technology Co. Ltd, China. Caov-3 cells were cultured with DMEM which contained fetal bovine serum (FBS; 10\%, v/v; Beyotime, China), penicillin-streptomycin (1\%, Sigma-Aldrich, USA) with $95 \%$ and $5 \% \mathrm{CO}_{2}$ at $37^{\circ} \mathrm{C}$. Caov-3 cells were seeded into sterile 6 -well plates. At a cell confluence of $80-90 \%$, cells were treated with vehicle $5,10,20$, and $50 \mu \mathrm{M}$ of zerumbone (Shyuanye, China) for $24 \mathrm{~h}$.

\section{3-(4,5)-Dimethylthiahiazo phenytetrazoliumromide (MTT) assay}

The MTT assay was conducted using a commercial MTT assay kit (Abcam, UK) according to the manufacturer's instructions. Briefly, Caov-3 cells were seeded into sterile 96well plates. Following treatment with zerumbone for $24 \mathrm{~h}$, the culture medium was removed, and $20 \mu \mathrm{L}$ MTT reagent was added and incubated for $3 \mathrm{~h}$ at $37^{\circ} \mathrm{C}$. Next, the MTT solvent was added and the 96-well plate was incubated on an orbital shaker for $15 \mathrm{~min}$. The optical density (OD) values at $590 \mathrm{~nm}$ were read in a spectrophotometer.

\section{Wound healing and Transwell assay}

Cell migration was examined using a wound healing assay. Caov-3 cells were cultured in 6well plates. At a cell confluence of $80-90 \%$, a straight line was scratched using a pipette tip on the bottom of the culture plate. Cells were then treated with different concentrations of zerumbone for $24 \mathrm{~h}$ as described above. The scratch width was photographed and measured under the microscope (Nikon, Japan).

Cell invasion was determined using the TranswellT assay. Caov-3 cells were cultured in the upper chamber of a 24-well insert (8- $\mu \mathrm{m}$ pore size; Corning, USA) that was precoated with Matrigel. The upper chamber was filled with FBSfree medium while the lower chamber was filled with FBS-containing medium. After treatment with zerumbone for $24 \mathrm{~h}$, cells on the upper side were removed, and the membrane was fixed with methanol and stained with crystal violet. Invading cells were imaged under the microscope, and their numbers were recorded.

\section{Western blot analysis}

After treatment with zerumbone for $24 \mathrm{~h}$, RIPA cell lysis buffer (Beyotime, China) and BCA Protein Assay Kit (Abcam, UK) were used to extract proteins and measure the protein concentration, respectively. Five micrograms of total protein were electrophoresed on a $10 \%$ polyacrylamide gel (SDS-PAGE) and then 
transferred to PVDF membranes (Merck KGaA, Germany). The membranes were then incubated with blocking buffer (Abcam, UK) for $1 \mathrm{~h}$ and incubated with the following primary antibodies: E-cadherin (sc-21791, 1:1,000), N-cadherin (sc8424, 1:2,000), Vimentin (sc-6260, 1:1,500), ZEB1 (sc-81428, 1:800), $\beta$-catenin (sc-7963, $1: 1,000)$, c-Myc (sc-40, 1:1,000), and GAPDH (sc-47724, 1:10,000). After incubation overnight at $4^{\circ} \mathrm{C}$, the membranes were probed with secondary antibodies (Santa Cruz, USA). The strength of the protein signal was detected with SignalFire ECL reagent (Cell Signaling, USA).

\section{Statistical analysis}

All statistical analyses were performed using GraphPad Prism 8.1.0 and the data are expressed as mean \pm SEM. Comparison between two groups was performed using oneway ANOVA followed by Bonferroni post hoc test. $P<0.05$ was considered significant.

\section{RESULTS}

\section{Zerumbone inhibited cell viability in Caov-3 cells}

Results from the MTT assay revealed that cell viability was inhibited by $5,10,20$, and $50 \mu \mathrm{M}$ zerumbone when compared with the control group, and this inhibition was concentrationdependent (Figure 2).

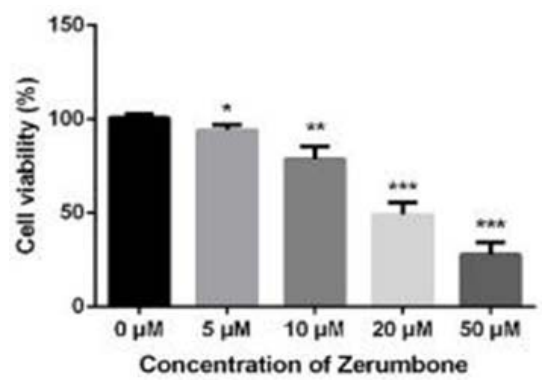

Figure 2: Effect of zerumbone on Caov-3 cell viability. ${ }^{*} p<0.05$ vs. ${ }^{* *} p<0.01$ vs. $0 \mu \mathrm{M} ;{ }^{* * *} p<0.005$ vs. 0 $\mu \mathrm{M}$

Zerumbone reduced cell migration and invasion in Caov-3 cells

Following treatment with zerumbone for $24 \mathrm{~h}$, the scratch width was larger in the cells treated with 10 and $20 \mu \mathrm{M}$ zerumbone than in those treated with vehicle alone. Zerumbone inhibited Caov-3 cell migration in a concentration-dependent manner (Figure $2 \mathrm{~A}$ ). The number of invading cells was reduced in cells treated with 10 and 20 $\mu \mathrm{M}$ of zerumbone, compared to vehicle-treated cells. Zerumbone inhibited Caov-3 cell invasion in a concentration-dependent manner (Figure 2 B).
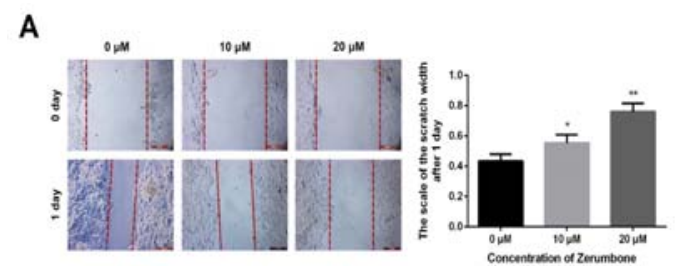

B
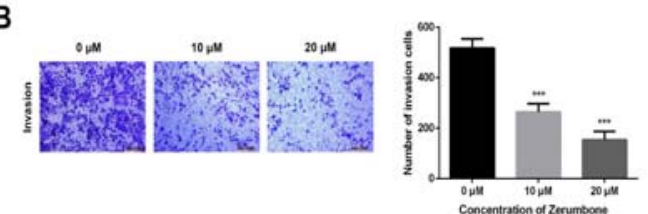

Figure 3: Caov-3 cell migration (A) and invasion (B) were inhibited by zerumbone; ${ }^{*} p<0.05$ vs. $0 \mu \mathrm{M}$; ${ }^{* *} p<$ 0.01 vs. $0 \mu \mathrm{M} ;{ }^{* * *} p<0.005$ vs. $0 \mu \mathrm{M}$

\section{Zerumbone prevented mesenchymal transition in Caov-3 cells \\ epithelial-}

After treatment with zerumbone for $24 \mathrm{~h}$, overexpression of E-cadherin was observed in cells treated with $5,10,20$, and $50 \mu \mathrm{M}$ zerumbone, and this upregulation of E-cadherin was enhanced in a concentration-dependent manner. The protein expression levels of $\mathrm{N}$ cadherin, vimentin, and zinc-finger E-box-binding 1 (ZEB1) were reduced in cells treated with 5 , 10,20 , and $50 \mu \mathrm{M}$ of zerumbone compared to those treated with vehicle alone, in a concentration-dependent manner (Figure 3).

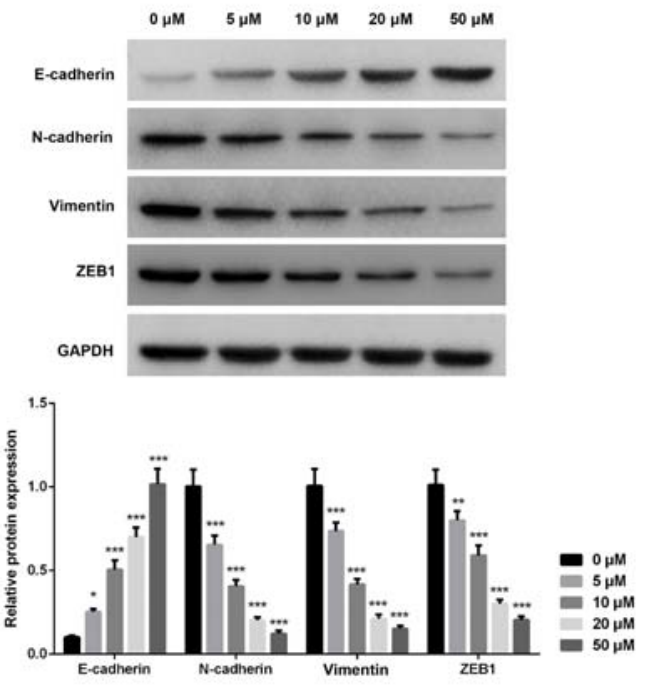

Figure 4: Epithelial-mesenchymal transition was suppressed by zerumbone; ${ }^{*} p<0.05$ vs. $0 \mu \mathrm{M}$; ${ }^{* * *} p<$ 0.005 vs. $0 \mu \mathrm{M}$ 
Zerumbone repressed the activation of Wnt/ $\beta$ catenin signaling pathway in Caov- 3 cells

Following treatment with zerumbone for $24 \mathrm{~h}$, the expression of $\beta$-catenin in the cytoplasm was upregulated in cells treated with $5,10,20$, and 50 $\mu \mathrm{M}$ zerumbone in a concentration-dependent manner. Expression of $\beta$-catenin in the nucleus was downregulated in cells treated with $5,10,20$, and $50 \mu \mathrm{M}$ zerumbone in a concentrationdependent manner. Suppression of c-Myc was observed in cells treated with $5,10,20$, and 50 $\mu \mathrm{M}$ of zerumbone in a concentration-dependent manner (Figure 4).
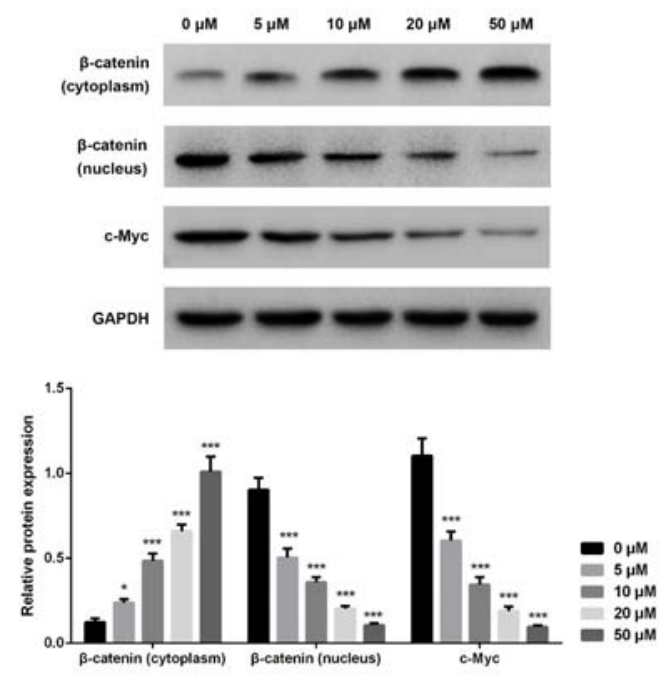

Figure 5: Activation of $\mathrm{Wnt} / \beta$-catenin signaling pathway was repressed by zerumbone; ${ }^{*} p<0.05$ vs. 0 $\mu \mathrm{M} ;{ }^{* \star *} p<0.005$ vs. $0 \mu \mathrm{M}$

\section{DISCUSSION}

The present study demonstrated that zerumbone plays an anti-tumorigenic role in ovarian cancer. Cell proliferation, migration, and invasion were prevented by zerumbone, consistent with findings in previous studies that zerumbone induced cell cycle arrest in ovarian and cervical cancer cells [16]. Furthermore, the EMT process was also repressed by zerumbone, confirming that zerumbone exerted protective and therapeutic effects on ovarian cancer. These results demonstrate that zerumbone might inhibit ovarian cancer progression and metastasis through the suppression of cell proliferation, migration and invasion, and by inhibiting the EMT process.

Initiation of the EMT is accompanied by the overexpression of mesenchymal marker proteins, such as N-cadherin, vimentin, and ZEB1, and suppression of E-cadherin, a cell adhesion molecule [17,18]. During EMT, upregulation of $\mathrm{N}$ cadherin contributes to cell mobility and invasion $\mathrm{s}[19]$. In this study, a reduction in $\mathrm{N}$-cadherin was observed after treatment with zerumbone, and cell migration and invasion were also inhibited by zerumbone, indicating that downregulation of $\mathrm{N}$ cadherin is associated with decreased cell migration and invasion. E-cadherin is typically expressed in epithelial cells, and loss of Ecadherin occurs during EMT in many cancers [20].

In this study, the expression of E-cadherin was increased with zerumbone treatment, indicating that the EMT process was reversed by zerumbone treatment. Furthermore, the expression of vimentinv and ZEB1 is required for the EMT in cancer [21]. Taken together, these data indicate that expression levels of $\mathrm{N}$ cadherin, vimentin, and ZEB1 were downregulated, and that of E-cadherin was upregulated, upon zerumbone treatment, suggesting that zerumbone prevents the EMT process and that all these four proteins involved in the EMT are potential therapeutic targets for ovarian cancer treatment.

Activation of the $W n t / \beta$-catenin signaling pathway has been observed in almost all types of ovarian cancers [22]. By binding to Wnt receptors, Wnt proteins induce the deactivation of GSK-3 $\beta$ through Ser9 phosphorylation, and release $\beta$ catenin, resulting in the translocation of activated $\beta$-catenin from cytoplasm to the nucleus, where $\beta$-catenin interacts with transcription factors to activate cell proliferation and survival [23]. In this study, $\beta$-catenin expression in both the cytoplasm and nucleus was increased in a concentration-dependent manner following treatment with zerumbone, demonstrating that translocation of $\beta$-catenin is inhibited by zerumbone.

C-Myc is one of the target genes of the $\mathrm{Wnt} / \mathrm{B}$ catenin signaling pathway [24]; overexpression of c-Myc has been observed in ovarian cancer, and contributes to platinum resistance in ovarian cancer [25]. The results of this study indicate that zerumbone causes a reduction in c-Myc expression in a concentration-dependent manner, with the consequent inactivation of the Wnt/ $\beta$-catenin signaling pathway and suppression of ovarian cancer progression. Because the $W n t / \beta$-catenin signaling pathway is involved in the regulation of EMT [9], the data from this study also indicate that suppression of the EMT by zerumbone is mediated via inhibition of the $W n t / \beta$-catenin signaling pathway. In summary, cell viability, migration, and invasion are repressed by zerumbone, indicating that its 
protective effects are mediated through the inactivation of the Wnt/ $\beta$-catenin signaling pathway.

\section{CONCLUSION}

The findings of this study indicate that zerumbone inhibits cell proliferation, migration, and invasion in ovarian cancer cells and also suppresses the EMT mediated by the activation of the Wnt/ $\beta$-catenin signaling pathway. Thus, zerumbone can potentially serve as a food supplement for the prevention of ovarian cancer as well as a potential therapeutic drug for the management of ovarian cancer.

\section{DECLARATIONS}

\section{Acknowledgement}

This study was supported by the Medical Science and Technology Research Funding of Guangdong Province (no. A2019364).

\section{Competing interest}

The authors state that there are no conflicts of interest to disclose with regard to this work.

\section{Contribution of authors}

We declare that this work was carried out by the researchers listed in this article. All liabilities related to the content of this article will be borne by the authors. QG designed all the experiments and revised the paper. $B E, E G$ and $L H$ performed the experiments. XW, NL and LW wrote the paper.

\section{Open Access}

This is an Open Access article that uses a funding model which does not charge readers or their institutions for access and distributed under the terms of the Creative Commons Attribution License (http://creativecommons.org/licenses/by/ 4.0) and the Budapest Open Access Initiative (http://www.budapestopenaccessinitiative.org/rea d), which permit unrestricted use, distribution, and reproduction in any medium, provided the original work is properly credited.

\section{REFERENCES}

1. Nimmagadda S, Penet M-F. Ovarian Cancer Targeted Theranostics. Front Oncol 2020; 9: 1537-1537.

2. Das PM, Bast Jr RC. Early detection of ovarian cancer. Biomark Med 2008; 2(3): 291-303.
3. Markman M. Pharmaceutical Management of Ovarian Cancer: Current Status. Drugs 2019; 79(11): 1231-1239.

4. Zhang $Y$, Weinberg RA. Epithelial-to-mesenchymal transition in cancer: complexity and opportunities. Front Med 2018; 12(4): 361-373.

5. Kalluri $R$, Weinberg $R A$. The basics of epithelialmesenchymal transition. J Clin Invest 2009; 119(6): 1420-1428.

6. Dongre $A$, Weinberg RA. New insights into the mechanisms of epithelial-mesenchymal transition and implications for cancer. Nat Rev Mol Cell Bio 2019; 20(2): 69-84.

7. Cordani $M$, Strippoli $R$, Somoza Á. Nanomaterials as Inhibitors of Epithelial Mesenchymal Transition in Cancer Treatment. Cancers 2019; 12(1): 25.

8. Logan CY, Nusse R. THE WNT SIGNALING PATHWAY IN DEVELOPMENT AND DISEASE. Annu Rev Cell Dev Bi 2004; 20(1): 781-810.

9. Nguyen VHL, Hough $R$, Bernaudo S, Peng C. Wnt/ $\beta$ catenin signalling in ovarian cancer: Insights into its hyperactivation and function in tumorigenesis. $J$ Ovarian Res 2019; 12(1): 122-122.

10. Clevers $H$, Nusse R. Wnt/ $\beta$-Catenin Signaling and Disease. Cell 2012; 149(6): 1192-1205.

11. Moreira da Silva T, Pinheiro CD, Puccinelli Orlandi $P$, Pinheiro CC, Soares Pontes G. Zerumbone from Zingiber zerumbet (L.) smith: a potential prophylactic and therapeutic agent against the cariogenic bacterium Streptococcus mutans. BMC Complement Altern Med 2018; 18(1): 301-301.

12. Rosa A, Caprioglio D, Isola R, Nieddu M, Appendino G, Falchi AM. Dietary zerumbone from shampoo ginger: new insights into its antioxidant and anticancer activity. Food Funct 2019; 10(3): 1629-1642.

13. Girisa S, Shabnam B, Monisha J, Fan L, Halim CE, Arfuso F, Ahn KS, Sethi G, Kunnumakkara AB. Potential of Zerumbone as an Anti-Cancer Agent. Molecules 2019; 24(4).

14. Hosseini N, Khoshnazar A, Saidijam M, Azizi Jalilian F, Najafi R, Mahdavinezhad A, Ezati R, Sotanian A, Amini $R$. Zerumbone Suppresses Human Colorectal Cancer Invasion and Metastasis via Modulation of FAk/PI3k/NFKB-UPA Pathway. Nutr Cancer 2019; 71(1): 159-171.

15. Kim S, Lee J, Jeon M, Lee JE, Nam SJ. Zerumbone suppresses the motility and tumorigenecity of triple negative breast cancer cells via the inhibition of TGF- $\beta 1$ signaling pathway. Oncotarget 2016; 7(2): 1544-1558.

16. Abdelwahab SI, Abdul AB, Zain ZNM, Hadi AHA. Zerumbone inhibits interleukin-6 and induces apoptosis and cell cycle arrest in ovarian and cervical cancer cells. Int immunopharmacology 2012; 12(4): 594-602.

17. Saitoh M. Involvement of partial EMT in cancer progression. J Biochem 2018; 164(4): 257-264.

18. Eastham AM, Spencer H, Soncin F, Ritson S, Merry CLR, Stern PL, Ward CM. Epithelial-mesenchymal transition events during human embryonic stem cell differentiation. Cancer Res 2007; 67(23): 11254-11262.

Trop J Pharm Res, July 2020; 19(7): 1369 
19. Hazan RB, Phillips GR, Qiao RF, Norton L, Aaronson SA. Exogenous Expression of $\mathrm{N}$-Cadherin in Breast Cancer Cells Induces Cell Migration, Invasion, and Metastasis. J Cell Biol 2000; 148(4): 779-790.

20. Wheelock MJ, Shintani Y, Maeda M, Fukumoto Y, Johnson KR. Cadherin switching. J Cell Sci 2008; 121(6): 727.

21. Satelli A, Li S. Vimentin in cancer and its potential as a molecular target for cancer therapy. Cell Mol Life Sci 2011; 68(18): 3033-3046.

22. Arend RC, Londoño-Joshi Al, Straughn JM, Buchsbaum $D J$. The Wnt/ $\beta$-catenin pathway in ovarian cancer: $A$ review. Gynecol Oncol 2013; 131(3): 772-779.
23. Chiarini $F$, Paganelli $F$, Martelli AM, Evangelisti $C$. The Role Played by Wnt/B-Catenin Signaling Pathway in Acute Lymphoblastic Leukemia. Int J Mol Sci 2020; 21(3): 1098.

24. Jia $X-X$, Zhu T-T, Huang $Y$, Zeng $X-X$, Zhang $H$, Zhang $W-X . W n t / \beta$-catenin signaling pathway regulates asthma airway remodeling by influencing the expression of $c$ Myc and cyclin D1 via the p38 MAPK-dependent pathway. Exp Ther Med 2019; 18(5): 3431-3438.

25. Reyes-González JM, Armaiz-Peña GN, Mangala LS, Valiyeva F, Ivan C, Pradeep S, Echevarría-Vargas IM, Rivera-Reyes A, Sood AK, Vivas-Mejía PE. Targeting cMYC in Platinum-Resistant Ovarian Cancer. Mol Cancer Ther 2015; 14(10): 2260-2269. 